\title{
Medicinal and Nutritional Values of Drumstick Tree (Moringa oleifera - A Review
}

\author{
Lovepreet Singh, Jyoti and Jatinder Singh*
}

Department of Horticulture, SAGR, Lovely Professional University, Punjab, India

*Corresponding author

\begin{abstract}
A B S T R A C T
\section{Keywords}

Classification,

Distribution,

Nutritional and

Medicinal, Water

Purification

Article Info

Accepted:

17 April 2019

Available Online:

10 May 2019

Moringa oleifera is also known as "Miracle Tree" and it's almost all parts have nutritional and pharmacological properties. It is highly nutritious crop cultivated mostly in all parts of the world. It is a valuable food crop, grows very fast and even beyond food it serves many benefits. It has been used to fight against malnutrition, especially among young ones and lactating mothers. Its various plant parts are used for different purposes. It is the richest plant source of Vitamins A, B, C, D, E and K. Minerals present in this tree include K, Mg, $\mathrm{Ca}, \mathrm{Mn}, \mathrm{Zn}, \mathrm{Cu}$, and $\mathrm{Fe}$. Its various parts are used for the treatment of various diseases. It is resistant to drought duration because of long taproot system. Its cultivation is very simple and requires fewer efforts. It plays an important role in conservation of soil, water, and mitigating climatic change. This review article provides a brief overview about the nutritional importance, health benefits, and their production technology including water purification properties.
\end{abstract}

\section{Introduction}

Moringa (Moringa oleifera Lam) is indigenous to Indian subcontinent and has become naturalized in the tropical and subtropical areas of the world. Tree occupies important position in the Indian vegetable industry. It is a drought tolerant, fast growing, perennial and easily adapted to diverse eco and farming systems. It is still supposed to be underutilized plant in family Moringaceae. Regional names of Moringa are Drumstick tree, Sajna, Horseradish tree, Mulangay, Kelor, Saijihan, and Benzolive, (Fahey, 2005). Almost all parts of the tree may be edible and have been consumed from long times. Moringa is cultivated in Tamil Nadu,
Andhra Pradesh, Kerala, and Karnataka in Indian states. Fuglie (1999) described many uses of Moringa tree like: biomass production, animal forage, biogas, domestic cleaning agent, in feeding programs to fight against malnutrition especially in Africa like countries, as blue dye, for fencing purpose, as fertilizer, green manure, for gum extraction and honey juice-clarifier, various medicines, as ornamental plantation, as bio-pesticide against seedling damping off, rope making, tannin purpose for tanning hides and water purification.

Almost all parts of the plant contain some remarkable properties including medicinal and pharmaceutical etc. Due to this reason, 
irrespective of the era and area the plants have always been important for humankind since commencement of life (Singh et al., 2012). All these properties make it unique biomaterials for food and allied uses. Different preparation from Moringa leaves, flowers, and fruits are used in Indian subcontinent for various purposes. Due to high nutritional value, it is a popular vital food source against PEM, which is quite common in under developed and developing countries.

It is used in more than 80 countries to relieve vitamin and mineral deficiencies, supporting cardiovascular system, blood-glucose levels, reducing malignancy by neutralizing free radicals, excellent support for antiinflammatory and immune system of the body. Above all, it has probable benefits in mental alertness, improvement in eyesight, general weakness, lactating mothers, menopause, bone strength, and depression (Nouman et al., 2014).

Moringa belongs to mono generic family named Moringaceae, and this family includes 12 species of various type trees etc. (Olson, 2002). Moringaceae family exhibits a wide range of tree forms, like bottle to cylindrical shaped trees, or tuberous type shrubs (Olson and Carlquist, 2001). Although Moringa tree is indigenous to India and Pakistan (Duke, 2001) but according to (Fahey, 2005) this genus is native to various countries like Afghanistan, Pakistan, Africa, Bangladesh, Namibia, India and Madagascar in the northwestern province of the Himalayans. This tree is extensively cultivated in dry areas of tropical type in Middle East and Africa (Nouman et al., 2013). Trees of Moringaare widely disseminated various tropical areas such as Ghana, Philippines, Ethiopia, Haiti Uganda, Nicaragua and several other nations of the world in which soil is suitable for survival of Moringa (Table 1).
It is a fast-growing, deciduous tree having height of 10-12 $\mathrm{m}$ and trunk diameter of 1.5 ft. It has an open crown of fragile, drooping branches and the leaves are tri-pinnate. The flowers are aromatic and five unequal yellowish-white petals. The flowers are about $1.0-1.5 \mathrm{~cm}$ long and $2.0 \mathrm{~cm}$ in diameter. They are produced on slender, hairy stalks in clusters, which are 10-25 cm lengthy. Flowering appears after 6 months of planting. In cooler regions, flowering occurs once in April and June month while in some areas, having constant seasonal temperatures and rainfall; flowering occurs twice or even all year-round.

The fruit is a three-sided brown colored capsule $20-45 \mathrm{~cm}$ sized dark brown seeds of diameter $1 \mathrm{~cm}$. Three whitish papery wings help the seeds to scatter by water and wind. During cultivation tree is cut back every year to 1 - 2 meter to limit height so that harvesting may became easy. The research work done at TNAU, which has modernized cultivation.

Moringa is grown in tropical and subtropical areas with annual rainfall of 760 to $2500 \mathrm{~mm}$ and temperature ranging from $18-28{ }^{\circ} \mathrm{C}$. It grows in any soil type except waterlogged ones. Slightly alkaline clay along with sandy loam soils is considered ideal due to their good drainage properties (Abdul, 2007) (Table 2).

\section{Present status in India}

In India, it is grown for its leaves flowers, and pods. Its pod is a prevalent vegetable in south part of India and appreciated for their noticeably inviting flavor. Marimuthu et al., (2001) stated that Moringa seeds have no dormancy, due to this property planting can be done soon after maturity and remain viable for up to one year. Spotty germination is recorded in case of older seeds. It flowers and 
fruit yearly but in some regions twice. Its cultivation is suitable for dry regions, as it is easy to cultivate without expensive irrigation methods.

Various types of planting systems are used for sowing purpose like; direct sowing and transplanting of young seedlings along with stem cuttings. 2 or 3 seeds, at depth of $2-3 \mathrm{~cm}$ and spacing of $1 \mathrm{~m}$ for leaf production while spacing should be more i.e. 3 to $5 \mathrm{~m}$ for production of seed, leaf and pod. It has been observed that Moringa gives better results with direct sowing. This tree may be easily cultivated in diverse eco systems and inhabits a distinctive position in the vegetable industry. In Southern India, best sowing time is September month. Sowing time should be exactingly followed otherwise the flowering will be overlapped with monsoon rains and ultimately result in flower shedding. The seed rate is 260-270 g/acre. Pinching is very necessary when the plant attains height of 75 $\mathrm{cm}$. This practice will stimulate the growth of side branches and the height of the tree is also limited. Kumar et al., (2000) observed that pinching of growing terminals at60 days after sowing seeds was better than pinching at 90 days. Fruits are harvested before they develop fiber. Approximate yield is 250-400 fruits/year/tree. In old garden of coconut in Tamil Nadu Moringa tree have been successfully cultivated as intercrop (Marimuthu et al., 2001).

A single gram of Moringa is important because its leaf powder contains 25 times iron of spinach, 10 times the vitamins of carrots, 9 times the protein of yoghurt, 0.5 times the vitamins of oranges, 15 times $\mathrm{K}$ of banana fruits, and 17 times $\mathrm{Ca}$ of milk. Apart from these fatty acids, minerals, and amino acids are also found (Teixeira et al., 2014). The leaves of Moringa tree are rich source of minerals and vitamins and exhibits antioxidant activity and phenolic compound like quercetin and kaempferol. Fresh leaves of Moringa are a good source of carotenoids with pro-vitamin A. They contain 6.6-6.8 $\mathrm{mg} / 100 \mathrm{~g}$ of $\beta$-carotene, greater thanapricots, pumpkin and carrots (Kidmose et al., 2006). Bark of Moringais boiled in water and soaked in alcohol to acquired drinks and infusions that can be used to cure various ailments joint pain, diabetes, hemorrhoids hypertension, poor vision, anemia, tooth ache, and uterine disorder (Yabesh et al., 2014).

\section{Medicinal properties}

These are used to cure health related problems like sore throat, ear infections, sprain, hypertension, cough, anxiety, headache, hysteria, skin infections, epilepsy, for intestinal worms, respiratory disorders, joints pain, anemia, blackheads, pimples cholera, diarrhea bronchitis, lactation diabetes, abnormal blood pressure, swelling chest congestion conjunctivitis, asthma, fever, scurvy, tuberculosis and semen deficiency (Mishra et al., 2012). Moringa tree have been proved to contain several chemical compounds having beneficial pharmacological properties with potential medicinal applications. They comprise cholesterol lowering compounds, antiulcer, hypoglycemic, with infectious skin curing, anti-hypertensive, antispasmodic, and anticancer properties (Anwar et al., 2007).

Moringa leaf extracts have been used to manage hyperthyroidism and anti-Herpes Simplex Virus Type-1 (Lipipun et al., 2003). Moringa pod and seeds contains high nutrients, and phytochemical compounds such as amino acid, vitamins $\beta$-carotene, protein, minerals, and various phenolics (Farooq et al., 2007). According to Ayurveda, traditional medicine system Moringa can prevent more than 300 diseases (Ganguly et al., 2013). Moringa seed oil also known as Ben oil and resists rancidity. In modern times, this tree 
has been promoted as an outstanding primary source of digestible calcium, protein, vitamin $\mathrm{c}$, and $\mathrm{Fe}$, carotenoids for consumption in undernourishment is a foremost concern. Moringa quantitatively offers higher nutrients per gram of plant than other plants. Moringa is used for malnourished children and for improvement of the immune system, against AIDS and HIV linked illnesses. It is also used in traditional medicine against various kinds of illnesses like recovery from liver impairment. Now it is being studied as a bioenhancer of nutrients and drugs because of its antibiotic properties (Lopez, 2011). By experimentation with rabbit, it has been revealed that anticipation of atherosclerotic plaque formation in arteries as well as the lipid and cardiovascular diseases, Moringa has therapeutic potential for the prevention of the same (Chumark et al., 2008). Researches indicate that Moringa leaf powder encourages neuro-protection and proves a promising pharmacological significance regarding ethno-medically and nutritionally well-being of nervous system (Hannan et al., 2014) (Table 3 and 4).

Table.1 Botanical classification

\begin{tabular}{|l|l|}
\hline Kingdom & Planate \\
\hline Division & Magnoliphyta \\
\hline Class & Magnoliopsida \\
\hline Order & Brassicales \\
\hline Family & Moringaceae \\
\hline Genus & Moringa \\
\hline Species & M. oleifera \\
\hline
\end{tabular}

Table.2 Geographic distribution of various species

\begin{tabular}{|l|l|l|}
\hline Shape of Tree & Name of species & Geographical location \\
\hline Slender shaped & & \\
\hline & Moringa concanensis & India \\
\hline & MoringaLam. & India \\
\hline & Moringa peregrina & Horn of Africa, Arabia Fiori Red Sea \\
\hline Bottle shaped & & \\
\hline & Moringa drouhardii & Madagascar \\
\hline
\end{tabular}

\begin{tabular}{|l|l|l|}
\hline & Moringa hildebrandtii & Madagascar \\
\hline & Moringa ovalifolia & S.W. Angola and Namibia \\
\hline & Moringa stenopetala & Ethiopia and Kenya \\
\hline Tuberous shrubs & & \\
\hline & Moringa arborea & North Eastern Kenya \\
\hline & Moringa borziana & Somalia and Kenya \\
\hline & Moringa longituba & Ethiopia, Kenya and Somalia \\
\hline & Moringa pygmaea & Somalia \\
\hline & Moringa ruspoliana & Somalia, Ethiopia, Kenya \\
\hline & Moringa rivae & Ethiopia and Kenya \\
\hline
\end{tabular}

Source-(Arora et al., 2013) 
Table.3 Medicinal uses and nutritional compositions of moringa

\begin{tabular}{|c|c|c|c|c|}
\hline $\begin{array}{l}\text { Particular } \\
\text { Part of } \\
\text { tree }\end{array}$ & Medicinal usages & Nutritional properties & Overall Benefit & References \\
\hline Leaves & $\begin{array}{l}\text { Treat headaches, hyperglycemia, scurvy, skin diseases, } \\
\text { Dyslipidemia, asthma, flu, syphilis, pneumonia } \\
\text { heartburn, malaria, ear infections, bronchitis, and } \\
\text { diarrhea, governs cholesterol and blood pressure, acts as } \\
\text { an anti-atherosclerotic agents, neuroprotectant, } \\
\text { antioxidant antimicrobial anticancer and anti-diabetic }\end{array}$ & $\begin{array}{l}\text { Contains proteins, fiber and various } \\
\text { minerals like } \mathrm{Mg}, \mathrm{Ca}, \mathrm{S}, \mathrm{K} \text {, and Fe and } \\
\text { Vitamins like } \mathrm{A}, \mathrm{B} \text {-choline, B1-thiamine, } \\
\text { riboflavin, ascorbic acid and nicotinic acid. } \\
\text { Amino acids like Arg, Val, Thr, Met, Trp, } \\
\text { His, Ile, Phe, Leu and Lys, are existing. } \\
\text { Various phytochemicals like saponins, } \\
\text { phenolics, sterols, quercitin tannins, } \\
\text { trepenoids, alkaloids besides flavanoids like, } \\
\text { glycoside, isothiocyanates, and isoquercitin, } \\
\text { kaemfericitin etc. }\end{array}$ & $\begin{array}{l}\text { Having antioxidant, } \\
\text { anti-diabetic and } \\
\text { anticancer agents, } \\
\text { anti-proliferative } \\
\text { properties. Vitamins } \\
\text { and minerals help in } \\
\text { improving immune } \\
\text { system. }\end{array}$ & $\begin{array}{l}\text { (Rockwood et al., 2013), } \\
\text { (Mbikay, 2012), } \\
\text { (Fuglie, 2005), } \\
\text { (Jung, 2014), } \\
\text { (Choudhary et al., 2013) }\end{array}$ \\
\hline Seeds & $\begin{array}{l}\text { Help in treating Chrohn's disease, STDs, epilepsy cramp } \\
\text { rheumatism simplex virus arthritis hyperthyroidism, anti- } \\
\text { herpes, gout and acts as anti-inflammatory and } \\
\text { antimicrobial agents }\end{array}$ & $\begin{array}{l}\text { Comprises oleic acid and antibiotic termed } \\
\text { as pterygospermin, along with several fatty } \\
\text { acids like linolenic acid, behenic acid, and } \\
\text { Linoleic acid. Some phytochemicals like } \\
\text { phytate flavanoids tannins lectins, saponin, } \\
\text { terpenoids and phenolics. In addition to it } \\
\text { some minerals, proteins, along with } \\
\text { vitamins like A, B, and amino acids and } \\
\text { fats. }\end{array}$ & $\begin{array}{l}\text { Anti-inflammatory } \\
\text { and anti-microbial } \\
\text { properties. }\end{array}$ & $\begin{array}{l}\text { (Rockwood et al., 2013; } \\
\text { Kasolo et al., 2010; Thurber } \\
\text { and Fahey, 2010; Sutalangka } \\
\text { et al., 2013; Nair and } \\
\text { Varalakshmi, 2011) }\end{array}$ \\
\hline $\begin{array}{l}\text { Root } \\
\text { Bark }\end{array}$ & $\begin{array}{l}\text { Contains cardiac stimulant compound, anti-inflammatory } \\
\text { and anti-ulcer property }\end{array}$ & $\begin{array}{l}\text { Some alkaloids substances like moriginine } \\
\text { morphine and minerals like magnesium, } \\
\text { sodium and calcium }\end{array}$ & $\begin{array}{l}\text { Antiulcer and a } \\
\text { cardiac stimulant }\end{array}$ & $\begin{array}{l}\text { (Adeyemi and Elebiyo, } \\
\text { 2014; Monera and } \\
\text { Maponga, 2012) }\end{array}$ \\
\hline Flower & $\begin{array}{l}\text { Anti-arthritic agents and hypocholesterolemic properties } \\
\text { which can cure urinary diseases }\end{array}$ & Contains $\mathrm{Ca}, \mathrm{K}$ and amino acids. & $\begin{array}{l}\text { Feasible for use by } \\
\text { beekeepers due to } \\
\text { nectar. }\end{array}$ & $\begin{array}{l}\text { (Fuglie, 2005; Sutalangka et } \\
\text { al., 2013) }\end{array}$ \\
\hline Pods & $\begin{array}{l}\text { Helps in treatment of joint pain, liver or spleen problems, } \\
\text { and diarrhea }\end{array}$ & $\begin{array}{l}\text { Rich in lipids non-structural carbohydrates, } \\
\text { protein, fiber and ash. Various fatty acids } \\
\text { like linoleic acid etc. are present }\end{array}$ & $\begin{array}{l}\text { In the diet of obese } \\
\text { because of PUFA }\end{array}$ & (Fuglie, 2005) \\
\hline
\end{tabular}


Table.4 Macronutrients of Moringa plant in various parts (gram/100gram of plant)

\begin{tabular}{|c|c|c|c|}
\hline Nutrients & Leaves & Seeds & Pods \\
\hline Carbohydrates & $0.1-10.6 \mathrm{~g}$ & $30-41 \mathrm{~g}$ & $0.1-5.0 \mathrm{~g}$ \\
\hline Proteins & $25-30 \mathrm{~g}$ & $29-38 \mathrm{~g}$ & $6.7-43 \mathrm{~g}$ \\
\hline Fibers & $0.1-28.5 \mathrm{~g}$ & $0.1-7.1 \mathrm{~g}$ & $0.1-27 \mathrm{~g}$ \\
\hline Lipids & $0.1-43.9 \mathrm{~g}$ & $0.1-21 \mathrm{~g}$ & $0.1-38 \mathrm{~g}$ \\
\hline
\end{tabular}

Table.5 Table showing treatment efficiency (\%) of both coagulants used

\begin{tabular}{lcc|}
\hline Dosage (mg L-i) & Aluminum sulphate (\%) & Moringa oleifera (\$) \\
\hline 0 & 0.00 & 0.00 \\
5 & 66.66 & 57.94 \\
10 & 52.79 & 44.09 \\
15 & 20.61 & 91.17 \\
20 & 21.25 & 73.48 \\
25 & 24.15 & 77.77 \\
30 & 24.04 & 77.69 \\
35 & 15.24 & 78.72 \\
40 & 4.46 & 78.05 \\
45 & 6.690 & 78.66 \\
50 & 70.86 & 78.72 \\
55 & 78.72 & 85.46 \\
60 & 3.260 & 83.40 \\
\hline
\end{tabular}




\section{Water purification properties}

Moringa seeds in powdered form may contain cationic polyelectrolytes, which work as a natural flocculent to clarify even the most muddled water. This powder joins with the solids present in the water and settles down. By doing so, it may remove $90-99 \%$ of bacteria that contained in water (Omotesho et al., 2013). Noteworthy finding of using Moringa oleifera as coagulant is the decreasing the primary levels of turbidity at $15 \mathrm{mg} \mathrm{L}-1$ with $91.17 \%$ of deletion efficiency where the minimum turbidity was attained even with reduced doses used compared to aluminum sulphate at $55 \mathrm{mg} \mathrm{L}^{-1}$ with $85.46 \%$ as recorded in Table 5.

Zand and Hoveidi (2015) have highlighted the significance of coagulant dosages on turbidity. Increased dosages may rise the cost of water treatment, which is not practicable. Alternative reason that why over-dosing should be escaped. Because there is a possibility of re-stabilization of the diluted particles to happen due to the saturation of the polymer bridge. It was reported that when concentration of seed powder was inclined from 0.016 to $0.08 \mathrm{~g} / \mathrm{L}$, rise in turbidity was recorded. Such phenomena may be defined by the existence of free positively charged particles of the flocculants resisting, leading to the flocks to the water. Pritchard et al.,(2010)reported that extract of the seed reduced the turbidity activity. They proved that seeds coagulate $80.0-99.5 \%$ turbidity process and efficiently leading to clear supernatant. This was simultaneously accompanied by a $90.00-99.99 \%$ bacterial load decrease in the sludge. Studies conducted by Adejumo et al., (2013) revealed that there was no significant difference in coli form count after treating water sample with different concentrations of Moringa leaf powder. This might be due to deviations in compound concentration, which helps to decrease coliform count. Quality of water treated with Moringa seed powder is enhanced through the proteins that encourage coagulation process (Santos et al., 2009).Various compounds like tannins and polyphenol, which are present in Moringa and have been described to retain antibacterial action (Khosravi et al., 2006). Moreover, humans (Anwar et al., 2007) also use Moringa seeds to normalize $\mathrm{pH}$ and govern the microbial load in the treatment of water for consumption. Research work carried out by (Salazar-Gámez et al., 2016) revealed that Moringa tree seeds were more effective and cheaper than aluminum sulfate in decreasing the turbidity of polluted water. Reduction in turbidity, microbial load, and micro particle content by seeds of Moringa as coagulants that can replace other normally used chemical coagulant like sand, which may be harmful to human, animal, and environmental health (Mangale et al., 2012).

Moringa plant contains more than 90 nutritional compounds including lipids, proteins, carbohydrates along with dietary fibers. It is mainly used as a food source to overcome malnutrition, especially in children and infants in the tropics.

\section{References}

Abdul, D.A.S., (2007). Economic Importance of Moringa oleifera in Tafa Local Government Area of Niger State NDE Project. Federal College of Forestry Mechanization, Kaduna, Nigeria.

Adejumo, O.E., Chekujekwy C. N., Kolapo A. L. and A. O. Olubamima (2013). Chemical analysis and investigative study on water disinfecting properties of (Moringaceae) leaf. J. Pharmacol., 3:530-4.

Adeyemi, O.S., and T.C. Elebiyo (2014). Moringa oleifera supplemented diets prevented nickel-induced 
nephrotoxicity in Wistar rats. J. Nutr. Metab., pp. 1-8.

Anwar, F.S., Latif M. Ashraf and A.H. Gilani (2007). Moringa oleifera: A food plant with multiple medicinal uses. Phytotherapy Research. 21:17-25.

Arora, D.S., Jemimah Gesare On sare, and Harpreet Kaur (2013). Bio prospecting of Moringa (Moringaceae): microbiological perspective. $J$ Pharmacogn. Phytochem., 1(6), 193215.

Basra, W., Nouman, Wasif, Shahzad Maqsood Ahmed Basra, Muhammad Tahir Siddiqui, Azra Yasmeen, Tehseen Gull, and Maria Angelica Cervantes Alcayde (2014). Potential of Moringa oleifera L. as livestock fodder crop: A review. Turk. J. Agric., 38: $1-14$.

Choudhary, M.K., S. H. Bodakhe and S.K. Gupta (2013). Assessment of the antiulcer potential of Moringa oleifera root-bark extract in rats. J. Acupunct. Meridian Stud., 6: 214-220.

Chumark, P., P. Khunawat, Y. Sanvarinda, S.Phornchirasilp, N.P. Morales, L. Phivthong-ngam, P. Ratanachamnong, S. Srisawat, and K.-u.S (2008). Pongrapeeporn. The in vitro and ex vivo antioxidant properties, hypolipidaemic and antiatherosclerotic activities of water extract of Moringa oleifera Lam. leaves. Journal of Ethnopharmacology. 116:439-446.

Duke, J.A., (2001). Moringa oleifera Lam. (Moringaceae). In: Handbook of Nuts (Ed. Duke JA). CRC Press, Boca Raton, FL, USA, pp. 214-217.

Fahey, J.W., (2005). Moringa oleifera: a review of the medical evidence for its nutritional, therapeutic, and prophylactic properties. Part 1. Trees for life Journal, 1(5), 1-15.

Farooq, A., S. Latif, M. Ashraf, and A. H. Gilani (2007). Moringa oleifera: a food plant with multiple medicinal uses. Phytotherapy Research: An International Journal Devoted to Pharmacological and Toxicological Evaluation of Natural Product Derivatives, 21(1), 17-25

Fuglie, L.J., (2005). The Moringa Tree: a local solution to malnutrition. Church World Service in Senegal, 75.

Fuglie, L.J., (1999). The Miracle Tree: Moringa oleifera: Natural Nutrition for the Tropics. Church World Service, Dakar. 68 pp.; revised in 2001 and published as The Miracle Tree: The Multiple Attributes of Moringa, $172 \mathrm{pp}$.

Ganguly, S., (2013). Indian Ayurveda and traditional medicinal implications of indigenously available plants, herbs, and fruits: A review. Int. J. Res. Ayurveda Pharm., 4, 623-625.

Hannan, M.A.J., -Y. Kang, M. Mohibbullah, Y.-K. Hong, H. Lee, J.-S. Choi, I.S. Choi, and I.S. Moon (2014). Moringa oleifera with promising neuronal survival and neurite out growth promoting potentials. Journal of Ethnopharmacology.152:142-150.

Jung, I.L., (2014).Soluble extracts from Moringa oleifera leaves with a new anticancer activity PLOS ONE, 9, pp. $1-10$.

Kasolo, J.N., G.S. Bimenya, L. Ojok, J. Ochieng, J.W. Ogwal-okeng (2010). Phytochemicals and uses of Moringa oleifera leaves in Ugandan rural communities.J. Med. Plants Res., 4, pp. 753-757.

Khosravi, A., and Behzadi A. (2006). Evaluation of the antibacterial activity of the seed hull of Quercus barantii on some gram-negative bacteria. Pak. J. Med. Sci., 22:429-32.

Kidmose, U., R. Y. Yang, S. H. Thilsted, L.P. Christensen, and K. Brandt (2006). Content of carotenoids in commonly 
consumed Asian vegetables, stability, and extractability during frying. $J$. Food Comp. Anal., 19, 562-571.

Kumar, A.R., M., Prabhu, V. Ponnuswami, V. Lakshmanan, and A. Nithyadevi (2014). Scientific seed production techniques in moringa. Agric. Rev., $35,69-73$.

Kumar, Vijaya and R. M. (2000). Studies on influence of months of sowing and growth regulation on annual moringa (Moringa pterygosperma Gaerth). Ph.D., Thesis, submitted to the Tamil Nadu Agricultural University, Coimbatore, India.

Lipipun, V., M. Kurokawa, R. Suttisri, P. Taweechotipatr, P. Pramyothin, M. Hattori and K. Shiraki. (2003). Efficacy of Thai medicinal plant extracts against herpes simplex virus type 1 infection in vitro and in vivo, Antiviral Research. 60:175-180.

Lopez, V., A. K. Jager, S. Akerreta, R. Y. Cavero and M. I. Calvo (2011). Pharmacological properties of Anagallis arvensis L. ("scarlet pimpernel") and Anagallis foemina Mill. ("Blue pimpernel") traditionally used as wound healing remedies in Navarra (Spain).

Ethnpharmaco.;134:1014-7.

Mangale, S.M., S.G. Chonde, and P.D. Raut (2012).Use of Moringa oleifera (drumstick) seed as natural absorbent and an antimicrobial agent for ground water treatment. Res. J. Recent Sci., 1(3) pp. 31-40.

Marimuthu, R., U. Athmanathan, and S. Mohan (2001). Changing scenario in the production systems of horticultural crops. South Indian Hort., 49: 34-36.

Mbikay, M., (2012). Therapeutic potential of Moringa oleifera leaves in chronic hyperglycemia and dyslipidemia: a review. Front. Pharmacol., 3, pp. 112.
Mishra, S.P., P. Singh and S. Singh (2012). Processing of Moringa oleifera leaves for human consumption. Bulletin of Environment, Pharmacology, and Life Sciences. 2:28-31.

Monera, T.G., and C.C. Maponga (2012).Prevalence and patterns of Moringa oleifera use among HIV positive patients in Zimbabwe: a cross-sectional survey, J. Public Health Africa, 3, pp. 6-8.

Nair, S., and K.N. Varalakshmi (2011).Anticancer, cytotoxic potential of Moringa oleifera extracts on HeLa cell line, J. Nat. Pharm., 2, pp. 138142.

Nouman, W., M. T.Siddiqui, S. M. A. Basra, H. Farooq, M. Zubair and T. Gull (2013). Biomass production and nutritional quality of Moringa oleifera as field crop. Turk. J. Agric. For., 37: 410-419.

Olagbemide, P.T., and P.C. Alikwe (2014). Proximate analysis and chemical composition of raw and defatted Moringa oleifera kernel. Adv. Life Sci. Technol., 24 pp. 92-99.

Olson, M. E. (2002). Combining data from DNA sequences and morphology for a phylogeny of Moringaceae (Brassicales). Syst. Bot., 27: 55-73.

Olson, M.E., and S. Carlquist (2001). Stem and root anatomical correlations with life form diversity, ecology, and systematic in Moringa (Moringaceae). Bot. J. Linn. Soc., 135: 315-348.

Omotesho, K.F, F. E. Sola-Ojo, T. R. Fayeye, R. O. Babatunde, G. A. Otunola, and T. H. Aliyu (2013). The potential of Moringa tree for poverty alleviation and rural development: Review of evidences on usage and efficacy. International Journal of Development and Sustainability, 2: 799-813.

Pritchard, M.T.,T Craven, A. S. Mkandawire, Edmondson, and J. G. O'neill (2010). 
A comparison between Moringa oleifera and chemical coagulants in the purification of drinking water-an alternative sustainable solution for developing countries. Physics and Chemistry of the Earth, 35; 798-805.

Rockwood, J.L., B.G. Anderson, and D.A. Casamatta (2013). Casamatta Potential uses of Moringa oleifera and an examination of antibiotic efficacy conferred by $M$. oleifera seed and leaf extract using crude extraction techniques available to underserved indigenous populations. Int. J. Phytothearpy Res., 3, pp. 61-71.

Salazar-Gámez, L.L, M. Luna-delRisco, and R. Salazar Cano (2016). Effect of storage and preparation methods of Moringa oleifera seeds during the coagulation process. Desalination and Water Treatment, 57(35), 1637616383.

Santos, A. F. S., Luz L. A., Argolo A. C. C., Teixeira J. A., Paiva P. M. G., Coelho L. C. B. B. (2009). Isolation of a seed coagulant Moringa oleifera lectin. Process Biochem., 44:504

Singh, Y., R. Jale, K. K. Prasad, R. K. Sharma, and K. Prasad (2012). Moringa oleifera: A Miracle Tree, Proceedings, International Seminar on Renewable Energy for Institutions and
Communities in Urban and Rural Settings, Manav Institute, Jevra, India, pp. 73-81.

Sutalangka, C., J. Wattanathorn, S. Muchimapura and W. Thukham-mee (2013). Moringa oleifera mitigates memory impairment and neuro degeneration in animal model of agerelated dementia, Oxid. Med. Cell. Longev., pp. 1-9.

Teixeira, E.M.B., M. R. B. Carvalho, V. A. Neves, M. A. Silva, and L. ArantesPereira (2014). Food Chem., 147, 5154.

Thurber, M.D., and J.W. Fahey (2010).Adoption of Moringa oleifera to combat under-nutrition viewed through the lens of the diffusion of innovations theory. Ecol. Food Sci. Nutr., 48, pp. 1-13.

Yabesh, J.E., S. Prabhu, and S. Vijayakumar (2014). An ethno botanical study of medicinal plants used by traditional healers in silent valley of Kerala, India. J. Ethnopharmacol., 154, 774789.

Zand, A.D., and H. Hoveidi (2015). Comparing aluminium sulfate and Poly-Aluminium Chloride (PAC) performance in turbidity removal from synthetic water. J. Applied Biotechnol., Rep., 2: 287-292.

\section{How to cite this article:}

Lovepreet Singh, Jyoti and Jatinder Singh. 2019. Medicinal and Nutritional Values of Drumstick Tree (Moringa oleifera - A Review. Int.J.Curr.Microbiol.App.Sci. 8(05): 19651974. doi: https://doi.org/10.20546/ijcmas.2019.805.228 